\title{
THE LEGAL IMPLICATIONS OF A NATIONAL POLICE FORCE*
}

\author{
Kiron Reid, University of Liverpool
}

\section{Introduction}

The increased centralised control of the police has been charted over more than ten years and is well documented. ${ }^{1}$ There are also well known arguments put in favour of a greater degree of centralisation and some in favour of a national police force. ${ }^{2}$ There are 43 geographic forces in England and Wales, 8 in Scotland, and the Police Service of Northern Ireland. ${ }^{3}$ The current controversy over merging police forces has lead to a great deal of debate but can be seen as following an historical pattern with earlier mergers in past decades. The 1990s saw the creation by statute of national policing bodies outside of the traditional tripartite structure in which local forces and local accountability are key elements. It can be argued that the country is nearer the creation of a single 'national' police force for England and Wales at least than ever before. ${ }^{4}$ The reviews of Cambridgeshire and Humberside forces following the investigation into the murder of Jessica Wells and Holly Chapman highlighted areas in which greater national cooperation would assist local police investigations for example. ${ }^{5}$ The merging of the National

* Thank you to Ian Dennis for encouragement and to Fiona Beveridge and the journal's anonymous referee for comments on an earlier draft of this paper. The usual disclaimers apply.

1 I. Oliver, "Police Accountability in 1996" [1996] Crim LR 611; N. Walker Policing in a Changing Constitutional Order (Sweet \& Maxwell, London, 2000); K. Reid "Current developments in police accountability" (2002) 66 Journal of Criminal Law 172; "The Police Reform Act 2002 - Increasing Centralisation, Maintaining Confidence and Contracting Out Crime Control" D. Ormerod and A. Roberts [2003] Crim LR 141 at pp.142-146; R. Sullivan "Police Reform Act 2002: A Radical Interpretation" [2003] Crim. LR 468; T. Newburn and R. Reiner "From PC Dixon to Dixon PLC: Policing and Police Powers Since 1954" [2004] Crim. LR 601 at pp.611-614.

2 Walker op. cit. p.29. S. Uglow, Criminal Justice, $2^{\text {nd }}$ ed. (Sweet \& Maxwell, London, 2002), pp.50-54. For an overview of the issues see S. H. Bailey, D. J. Harris and D. C. Ormerod, Bailey, Harris \& Jones Civil Liberties: Cases and Materials, 5th ed. (Butterworths: London, 2001) pp.95-100. "A National Police Service: Any Day Now?” D. Donnelly, K. Scott \& R. Wilkie (2002) 75 Pol. J. 287 with detailed debate about the police in Scotland.

3 For detail on each see M. McBride and G. Collins, The UK Police: A Pocket Guide 2002-2003 (Pen and Sword Books: Barnsley, 2002); also <www.police.uk> a site maintained by the Police Information Technology Organisation (PITO) on behalf of the Association of Chief Police Officers (ACPO).

${ }^{4}$ Generally see discussion in the White Paper One Step Ahead: A 21st Century Strategy to Defeat Organised Crime, Cm 6167, March 2004, pp.21-27. Consultation Paper Policing: Building Safer Communities Together (Home Office, London, 2003) discussion at 25-27.

5 The Bichard Inquiry Report, HC653 (HMSO, London, 2004) pp.13-17 especially recommendations 1-5. See also Report by Sir Michael Bichard's reconvened Inquiry to establish progress on delivering the recommendations made in his 
Criminal Intelligence Service (NCIS) and National Crime Squad to create the Serious Organised Crime Agency (SOCA) can be seen as a logical rationalisation to enable the police to respond more effectively to serious and organised and trans-national crime. ${ }^{6}$ On the other hand it could be seen as the first step in the creation of a national police force, to be followed by the abolition of the county based police forces.

For the time being the Government does not appear to be about to embark on such a policy. For example there was no hint of this in the Queen's Speech for the Labour Government's third term. ${ }^{7}$ Instead this debate was dramatically opened up by the publication of a report by Her Majesty's Inspectorate of Constabulary (HMIC) calling for a reduction in the number of police forces in England and Wales and the creation of strategic police forces in each region as the preferred option. ${ }^{8}$ The then Home Secretary supported this option which was subsequently supported by the next Home Secretaries, at least initially (below). ${ }^{9}$ The Police Superintendents' Association responded by renewing its call for a national police force. ${ }^{10}$ The Government have not supported that proposal. However the centralisation of the police that has occurred by 2006 would have been unprecedented even in 1985 and the idea of further wholesale centralisation cannot be ruled out within the next ten years.

This article examines the potential legal implications of establishing a national police force, as well as briefly looking at some of the arguments about accountability. Concerns about lack of local accountability, and the benefit of a possible increase in central accountability, are both considered. The article concludes that the Government could create a national police force by legislation relatively simply and with few legal problems as obstacles to doing so. The aim of this article is not to consider the theoretical arguments for or against national policing or to advocate in favour of or against a national police force. However it will make a clear conclusion based on analysis of the trends in police accountability as to how the Government could be more honest in the debate about policing. The article will mainly consider England and Wales but Scotland and Northern Ireland

original report. 15 March 2005 (HMSO, London), p.iv. Website <http://www.bichardinquiry.org.uk/> as at 17 June 2005.

6 Accountability issues relating to the establishment of SOCA are noted in K. Reid "The Home Secretary and Improved Accountability of the Police?" (2005) 69 JCL 232 at 252-253, and considered further below.

7 HL Debs, Vol. 672, Col. 5, 17 May 2005. Also White Paper, supra, p.27; Policing: Building Safer Communities Together - Summary of consultation responses (Home Office, London, 2004) pp.33-36.

8 Closing the Gap - A review of the 'Fitness for Purpose' of the current structure of policing in England and Wales by HM Inspector of Constabulary Denis O'Connor $C B E, Q P M .16$ September 2005.

9 Home Office Press Release (HOPR) "Home Secretary Calls on Police to Undertake Radical Reform of Structures" 19 September 2005. Compare the media reaction of the Daily Express "POLICE CRISIS" "Super-forces planned as chiefs say: We can't cope" front page and the BBC "Cost warning on police shake-up" BBC news online, both 17 September 2005.

10 See Rick Naylor's President's address to the national conference, 29 September $2005<\mathrm{http} / / /$ www.policesupers.com/scripts/P_index.html> viewed at 6 October 2005 . 
will also be examined in places. This article will not reprise the theoretical arguments in detail but is more concerned about how such change could be effected. ${ }^{11}$ O'Connor concluded in his report (para. 1.60): "the 43 force structure is no longer fit for purpose. In the interests of the efficiency and effectiveness of policing it should change." In the Autumn of 2005 police chiefs were asked to put forward proposals for merging forces. A reduction from 43 to 17 was likely. Given that scenario a single national force may not be such a dramatic alternative. Even given that mergers were put on hold and then apparently stopped when John Reid had a change of heart due to local and national political opposition the debate over the structures of the police will not go away. ${ }^{12}$ This included stopping the one 'voluntary' merger of Cumbria and Lancashire that had been agreed by those Police Authorities in response to being told that smaller forces must merge proceeding. ${ }^{13} \mathrm{~A}$ member of West Yorkshire Police Authority predicted that mergers themselves would come back in the future, no matter whether party changed and the continuity in policy between Labour and Conservative Governments make that appear a likely true prediction. ${ }^{14}$

\section{The Current Policy Setting}

The tripartite system of police accountability divided responsibility between the local police Chief Constable (each force generally covering one or sometimes more counties), the police authority made up of local representatives including councillors and magistrates, and the Government Minister the Home Secretary. This system was set out in the Police Act 1964 and though that was replaced, heavily amended and updated by the Police Act 1996, the basic structure is the still the structure of accountability in place today. Amendments since the early 1990s have made the system significantly different from that in the Police Act 1964. In the Police and Magistrates' Courts Act 1994 under the Conservatives the Home Secretary was given the power to set objectives for the policing of the areas of all police authorities, and set performance targets. ${ }^{15}$ 'Independent' members were introduced appointed from a short-list approved by the Government minister. With the creation of the National Crime Squad and National Criminal Intelligence Service by the Police Act 1997 national statutory policing bodies were introduced for the first time. Policy continuity was apparent under the Labour Government from 1997 onwards, although local

11 For incisive debate on the meaning of accountability in the context of the police see S. Spencer, Called to Account, (NCCL, London, 1984), Introduction, pp.1-8.

12 See letter from the Home Secretary and force restructuring news, as at 19 June 2006.http://police.homeoffice.gov.uk/police-reform/force-. Restructuring HOPR "Home Secretary delays police force mergers" 20 June 2006. For examples of media coverage "Police forces merger plan will be scrapped, says chief constable" The Independent 11 July 2006. "Government scraps police merger plans" The Huddersfield Daily Examiner, 13 July 2006 and editorial. http://ichuddersfield.icnetwork.co.uk/.

13 "Home Office Fails to Meet Police Authority Conditions for Amalgamation" Cumbria Constabulary Press Release 10 July 2006. $<\mathrm{http}: / /$ www.cumbria.police.uk/news_4908.htm $>$ See the Prime Minister's statement at H.C. Debs Vol. 448, Col. 1383, 12 July 2006.

14 Cllr. Tony Woodhead, letter The Huddersfield Daily Examiner, 13 July 2006.

15 Incorporated as ss.37 and 38 of the Police Act 1996. 
inter-agency cooperation was stressed by the Crime and Disorder Act 1998 . The Criminal Justice and Police Act 2001 continued the trend towards the establishment of national policing structures, this time for police training. The Act set up a Central Police Training and Development Authority (Centrex) and gave the Home Secretary power to set regulations about training. The Police Reform Act 2002 introduced the National Policing Plan. For the first time the Government's priorities, performance indicators and plans for new development of policing have been brought together in a single document. At the same time the Act greatly enhanced the role of the Government Minister to intervene in and give guidance to police forces and police authorities both generally and specifically. This included in Part 1 enhanced powers regarding inspection of policing in the areas and in Part 3 regarding the removal and suspension of senior officers. The Home Secretary had always had powers in the tripartite structure regarding inspection and to make regulations but the totality of the reforms since 1994 have put the Government in a far stronger position than previously vis a vis local police chiefs and police authorities. One strength of the 'New Labour' approach has been that the Government is willing to overturn policies if it decides that they are not working. On the other hand this can lead to an alarming pace of change. Key policy innovations such as the National Policing Plan and creation of Centrex for police training discarded after just a few years by the Police and Justice Act 2006. However the key recent theme of increased Government influence remains strong. ${ }^{16}$

Jones and Newburn make the point that there is much continuity as well as radical change in policing and that many new approaches have in fact been found in the past. ${ }^{17}$ This can be illustrated by referring to many well known works from the recent history of policing and criminal justice literature that show debate about the same legal, policy and operational issues as today. A fairly random search by the author for instance records the following examples: the discussion of flaws in police accountability by Kinsey, Lea and Young: ${ }^{18}$ a call for independent scrutiny of police complaints in America by Morris and Hawkins; ${ }^{19}$ similarly their expressing concern about corruption in the 1980s calling for very similar reforms as proposed a decade earlier and introduced in Britain and to some extent in the USA in more recent times. ${ }^{20}$

In Crime - Cause \& Cure Conference, Conference Report Liverpool and Bootle Constabulary Chief Constable J. Haughton in the introduction describes the policy adopted in 1970 "to more closely identify the police with community life and to join with the community in seeking solutions for

16 The Police and Justice Act received Royal Assent on 8 November 2006 after preparation of this article. Key changes are noted here. Centrex replaced by the National Policing Improvement Agency (NPIA), operational from 1 April 2007.

17 "The Transformation of Policing? Understanding Current Trends in Policing Systems" (2002) 42 Br J Criminol 129, particularly at 142-3.

18 R. Kinsey, J. Lea \& J. Young Losing the Fight Against Crime (1986) chap.8.

19 N. Morris and G. Hawkins the honest politician's guide to crime control (1970) pp.98-101.

20 E. Mallow The Ethics of Law Enforcement and Criminal Punishment (1982) chap.2. 
many neighbourhood problems". ${ }^{21}$ Twenty five years later the Chief Constable of Northern Ireland devotes two of the twelve pages of his report to community issues and the Merseyside Chief Constable produces for the fourth year five area versions of his Annual Report. ${ }^{22}$

The debate over a national police force has returned more strongly than at any time since the majority Royal Commission rejected this option in 1963.23 Various writers have recently pondered the issue as to whether there are moves towards creating a national force. Writing in 2001 Bailey, Harris and Ormerod pose the question whether there is a de facto national police force. ${ }^{24}$ Implicitly the answer is not at the moment. On the other hand the five trends in policing identified by the authors in December 2001 all continued as predicted including increased centralisation. These are the development of European policing, increased centralisation, increased 'militarisation' of the police (plastic bullets and tasers being deployed subsequently), increased use of surveillance techniques, the rise in the private security industry. ${ }^{25}$

Sir Michael Bichard's reconvened Inquiry noted recent developments in national coordination.

"The apparently strong commitment of forces to the development of the national IT intelligence system (IMPACT) is further evidence of a more corporate approach by the service, while the advent of the National Policing Improvement Agency augurs well for a more effective approach to developing and disseminating best practice in support of operational policing." 26

Government thinking was found in the March 2004 White Paper. This discusses the "strategic capacity of existing police forces". The paper observes:

'one option may lie in developing fewer, more "strategic" forces across the country and identifying forces to act as "lead" forces on specific issues, so acting as a focal point for intelligence and expertise. ${ }^{27}$

This development was predicted by Uglow. ${ }^{28}$

Opponents of centralisation and a national police force have emphasised the importance of local governance as a precaution against tyranny and practically as an effective means of dealing with local concerns. There is nothing in UN or EU or Council of Europe principles or ECHR jurisprudence that necessarily requires local police forces and local

21 Liverpool and Bootle Constabulary, University of Liverpool September 1973 (report January 1974).

22 Respective Annual Reports 2004/05 published by PSNI Belfast (pp.6-8) and Merseyside Police, Liverpool. Thanks to Tim Moore, Merseyside Police Authority, for up to date information.

23 Royal Commission on the Police, Final Report Cmnd. 1728 (1962).

24 Op. cit., p.99-100.

25 Ibid., pp.147 - 151.

26 Op. cit., p.iv.

27 Op. cit., p.27.

28 Op. cit., p.53. 
accountability. General Assembly resolution 34/169 of 17 December 1979 Code of Conduct for Law Enforcement Officials requires that: "every law enforcement agency should be representative of and responsive and accountable to the community as a whole." This could be at local or national level, however. ${ }^{29}$ At the same time the Home Secretary, in supporting larger forces, has critically stressed the continued importance of making the police accountable to their local community. This is through emphasis on local cooperation. ${ }^{30}$ This concept of, in effect, accountability through partnership will be considered in more detail below. Trends in police policy in the UK have matched those in other jurisdictions. ${ }^{31}$ Ormerod and Roberts described the scene for the major reforms by Tony Blair's second Government.

\begin{abstract}
"the Secretary of State acquires greater powers which may be exercised in relation to matters including those of an operational nature; although not to the extent originally proposed in the Bill. ... It was suggested the Bill represented a move "by stealth ... . unnoticeably and slowly towards a national police force." [Lord Carlisle]"
\end{abstract}

They conclude that there was "a limited shift towards centralised power, without completely undermining the tripartite structure" but "[n]evertheless, the safeguards against abuse of the Secretary of State's enhanced powers rest only in obligations of consultation and report, which will ensure that there is at least transparency in the process." 32 Sullivan believes that "the 2002 Act already amounts to change that overturns the tripartite structure of British policing." ${ }^{33}$ Creating a national police force and giving the Home Secretary more explicit powers would remove any confusion about lines of accountability. The tripartite structure allows each party to imply that another party is responsible for any failure or lack of performance. Giving the Home Secretary responsibility would enable Parliament to clearly hold the Home Secretary to account and to monitor police performance more closely.

Newburn and Reiner, like Bailey and co-authors, note a de facto national control legitimised by the myth of the tripartite structure. They conclude "it is difficult to see how this centralising and managerialising tide is to be turned back." ${ }^{34}$

One argument in favour of centralisation is that local control is not necessarily effective at protecting civil rights or holding the police to account. There are problems with local accountability in this context. Galligan

29 For more analysis see: Human Rights and Law Enforcement: A Manual on Human Rights Training for the Police, Ch. IX Policing in Democracies, pp.39, 40 (Office of the United Nations High Commissioner for Human Rights, Professional Training Series No. 5). Available at www.ohchr.org as at September 2005.

30 HOPR 19/09/2005, above.

31 For an overview of developments in Australia, Britain and the United States refer to C. Edwards, Changing policing theories for 21st century societies (Federation Press, Sydney, 2005) 2nd ed.

32 Loc. cit. p.142.

33 Loc. cit. p.469.

34 Loc. cit. p.618. 
has warned 'Local control also has its dangers: small communities can be repressive and intolerant of minority interests' ${ }^{35}$

While this writer has rejected Crawford's critique of a "mythical golden age" of local accountability precisely because it was clearly an argument set up to be knocked down, it is fair to highlight that local control has often not been seen to provide appropriate safeguards for the public. ${ }^{36}$ This was true historically as well as in recent times. The arguable failure of Humberside Police Authority to take account of public concern was highlighted by the Home Secretary taking legal action against the Authority. ${ }^{37}$ This same Authority was the subject of a judicial review over the composition of the elected members of the Authority in December 2000. This was a political row over the political composition. The High Court upheld a decision by the Joint Committee for the Purpose of Making Appointments to the Humberside Police Authority to disregard independent councillors in the exercise of its duty to ensure that the members it appointed reflected the balance of parties among the members of the relevant councils taken as a whole. Mrs. Justice Rafferty stated that the law was clear. ${ }^{38}$ However had the Joint Committee followed the advice of their clerk (at paragraph 5) this matter may never have reached court. Arguably a membership that took account of the existence of independent members would have better reflected local opinion. That position was supported by the view of the national government department (letter from the Home Office referred to at paragraph 19) but not reflected by the majority of local political representatives on this committee in Humberside. In Devon and Cornwall by contrast there are independent councillors as members on the Police Authority. One from Cornwall and one Isles of Scilly. The political parties here clearly take a different view about the groups that should be represented. ${ }^{39}$

In various areas of Government policy there is a clear trend of taking accountability away from democratic local institutions in the name of increasing local control, whether this is done directly by central Government or by new public bodies. Concern over the centralising effect of Government local government policy have been prominent in media reports. ${ }^{40}$ Examples can be found across the spectrum of organisations, for example from the

35 D. Galligan, "Regulating Pre-Trial Decisions", in I. Dennis (ed.) Criminal Law and Justice (1987) p.198.

36 (2002) 66 JCL 178.

$37 R$ (Secretary of State for the Home Department) v Humberside Police Authority [2004] EWHC 1642. See Reid (2005) pp.240-242.

$38 R . \mathrm{v}$ Joint Committee for the Purpose of Making Appointments to the Humberside Police Authority Ex p. East Riding of Yorkshire Council (2001) 3 L.G.L.R. 46, para.31. Transcript accessed via the Westlaw database.

39 Thank you to Sarah Henley of Devon and Cornwall Police Authority for providing the most up to date information.

40 For example see "Councils seek control of their own destiny" The Times, Public Agenda supplement, 5 July 2005, p.3; P. Hetherington "Comment extra" p.9 The Guardian, Society Guardian supplement, 6 July 2005, and $c f$ M. Dean "Opinion" p.5. 
NHS a local dispute over an appointment to the Liverpool Women's Hospital Council. ${ }^{41}$

Potential legal and political obstacles to the creation of a national police force are considered below.

\section{The Shift from Accountability to Management.}

The 'left' in British politics traditionally campaigned in support of greater local control and political accountability of the police. ${ }^{42}$ For example Jack Straw, the first Home Secretary in Tony Blair's cabinet, put forward two bills in support of greater democratic control - in 1979 and in $1980 .{ }^{43}$ The current Labour Mayor of London supported radical policies relating to the police when he was Leader of the Greater London Council in the mid1980s. ${ }^{44}$ Residual vestiges of that traditional support for local accountability have largely been replaced by managerial and results led concern to deliver progress in actual and perceived public safety. For example in the police reform agenda the Government were not interested in the traditional Labour and Liberal policy to remove unelected magistrates from police authorities. This was illustrated when Liverpool City Council (controlled by the second opposition political party, the Liberal Democrats) passed a resolution to lobby Government "to drastically reduce the number of non-Councillor members of Police Authorities and thereby reduce the current democratic deficit”. John Denham MP (then Minister for Police Reform) wrote in a detailed and thoughtful reply:

"On the point of the composition of police authorities, we have no plans to introduce legislation to alter the current pattern. We are, as you know, engaged on a major programme of police reform with the aim of both reducing crime and the fear of crime. I do not think it would help if we added a further major element of change to the already significant developments we have in train." 45

New ways of charting police performance were introduced. The Audit Commission can evaluate the Best Value Performance Plans produced by each Police Authority under the Local Government Act 1999. They issue an annual audit letter and liaise with Her Majesty's Inspectorate of

41 Considered at Liverpool City Council's Executive Board, 10 June 2005, item 3. Government research can be found in Office of the Deputy Prime Minister New Localism- Citizen Engagement, Neighbourhoods and Public Services: Evidence from Local Government. (ODPM, 2005) and an official view in ODPM News Release 2005/0140, 20 July 2005, "Further measures to cut burden of red tape".

42 M. Simey, "Police Authorities and Accountability: The Merseyside Experience" in D. Cowell, et. al., Policing the Riots (1982). E. Mclaughlin, Community, policing and accountability: the politics of policing in Manchester in the 1980s (1994).

43 See Jack Straw H.C. Debs, Vol. 322, Col. 78415 December 1998. S. Spencer, Called to Account, $($ NCCL, 1984), especially chaps. 3, 5 \& 6 .

44 G. Marshall and B. Loveday, "The Police: Independence and Accountability" chap.11 in J. Jowell \& D. Oliver (eds.), The Changing Constitution, 3rd ed. (1994) p.311.

45 Letter to David Henshaw, Chief Executive Liverpool City Council, 19 July 2002, responding to motion moved by Cllr. Paul Clein 24 April 2002 and subsequent correspondence. 
Constabulary and can produce national or local themed reports including joint reports. ${ }^{46}$ HMIC inspects individual police forces and parts of police forces (geographical Basic Command Units or particular sections) as well as carrying out themed reports. Most recently Baseline Assessment was introduced by HMIC / Home Office in $2003-04 .{ }^{47}$

Political concern to deal with real and perceived crime and disorder has been the key feature of Labour policy relating to the police. This has involved the police in greater partnership working, conscious that the police cannot tackle social problems alone. It has led to direct political intervention in areas of greatest public concern, for example concerning street robbery. ${ }^{48}$ More significantly year on year it is targeted at two levels. The police and other agencies locally, supported by Government, dealing with the amorphous concept of 'anti-social behaviour' and nationally the police concentrating on serious and organised and transnational crime. ${ }^{49}$

This article assumes that SOCA would remain separate to the new national police force with the same remit amended to include support to and work with the national police force. The national police force would concentrate on domestic crime, policing and community safety issues while officers would work with SOCA on tackling serious, organised and transnational crime. This article also envisages that the 'national' police force would be for England and Wales only. Policing is largely a devolved matter in Scotland. ${ }^{50}$ In Northern Ireland reforms were an integral part of the peace process following the Good Friday Agreement and the Patten Report. ${ }^{51}$ Therefore legislation of a constitutional significance would be needed to change those settlements by merging the police forces in Scotland and the Police Service of Northern Ireland (PSNI) with the police forces in England and Wales. The Scottish Executive (though not it appears Parliament) have

46 For example the first Avon and Somerset Police Authority External Audit 2002-03 Annual Audit Letter, p.22 (Audit Commission, London, November 2003).

47 For an explanation of baseline assessment see The Role of Her Majesty's Inspectorate of Constabulary (HMIC, 2004) pp.6-8 available at <http://www.homeoffice.gov.uk/hmic/hmic.htm> as at 15/12/04.

48 "Problem-solving street crime: practical lessons from the Street Crime Initiative" N. Tilley et. al., (Home Office, London, 2004) p.2; K. Reid "Policing the railways and related legal issues" (2003) 67 Journal of Criminal Law 495 p.506-07.

49 A recent useful summary of the distinction between high and low policing is found at the start of "'Eye Spy Private High' Re-Conceptualizing High Policing Theory" C. O'Reilly \& G. Ellison (2006) 46 Br J Criminol 641.

50 Scotland Act 1998 ss.28-30, schs.4 and 5. See also the Police (Scotland) Act 1967 as amended by the Police and Magistrates' Courts Act 1994 and Police Reform Act 2002. The devolution of power to Scotland largely recognised the existing separate criminal laws of Scotland. See G. Gordon, Renton \& Brown: Criminal Procedure, $6^{\text {th }}$ ed. (W Green \& Son Ltd., Edinburgh, 2001 update), chap. 1 and ibid., Sch.5 Part II, particularly Head B.

51 See A New Beginning: Policing in Northern Ireland. The Report of The Independent Commission on Policing for Northern Ireland (1999) available at <http://www.belfast.org.uk/> at 22 July 2005; The Police (Northern Ireland) Act 2000; K. Starmer and J. Gordon "Monitoring the Performance of the Police Service in Northern Ireland for Compliance with the Human Rights Act 1998" [2005] EHRLR 233; M. Tomlinson \& P. Hillyard "Patterns of Policing and Policing Patten" (2000) 27 J. Law \& Soc. 394. 
considered creating a single Scottish police force. ${ }^{52}$ They decided to keep the current eight forces after a review in 1999 - 2000. The review concluded:

"The creation of a national police force would be the most radical option but while viable it would raise significant controversy, not least in terms of local accountability and civil liberties issues. . . . the current forces are well established and are working effectively. . . . The sub-group therefore favours retaining the existing 8 force structure." 53

There is no reason of legal principle however why they could not decide to have a single force - whether or not this is done in England and Wales. More detail on the Scottish work is considered below. It can be argued creating a national police force in any of the jurisdictions of the UK would be a change of constitutional significance, perhaps necessitating a referendum. On the other hand it appears anachronistic today - even comical - that there were 120 police forces in England and Wales prior to the Police Act 1964 and reorganisation in 1974 reducing the number to 43. There may be nostalgic affection and support for the old Rutland, Flintshire or City of Liverpool Constabularies but it would untenable to argue today that each small area have its own separate force (though the Government wish to convince the public as to the importance of local policing, below). It is possible that in the future the idea of the UK not having had a national police force or forces will appear equally historically daft. This author finds it impossible to suggest that if Robert Peel were to appear today with the idea of setting up a police force that this would prove so controversial Parliament would be asked to agree to set up a police force for London only, or that it would take a decade to allow rural areas to establish modern police forces. ${ }^{54}$

\section{The Scottish Model v The SOCA Model. ${ }^{55}$}

Work in Scotland from 2001 to date has centred on establishing a single body to run common police services. These include the Scottish Police College (SPC), Scottish Criminal Record Office (SCRO) and Scottish Police Information Strategy (SPIS) which are already in existence and a new national forensic science service for Scotland. Supporting Police, Protecting Communities: Proposals for Legislation, chapter 2, set out proposals for the

52 See Scottish Office News Release 1167/99 9 June 1999 "No hidden agenda on force restructuring Wallace tells Chief Constables"; Scottish Executive News Release SE2853/2000 6 November 2000 "Strengthening Police Services". Useful discussion of the position in Wales is found in Sullivan loc. cit. p.469, who also raises present day concerns about regionalisation.

53 Review of Police and Fire Services, Police Review: Interim Report (Scottish Executive, Edinburgh, 2000) paras.56-57. Thanks to Laura Duffy, Police Division, for supplying a copy of this report.

54 Though the increasing use of police against peaceful protesters may resonate given that rural forces were set up to control the pro-democracy Chartist movement. Metropolitan Police Act 1829 established a police force in London. County Police Act 1839 allowed rural areas to create police forces. For detailed study see C. Emsley Crime and Society in England 1750-1900, $1^{\text {st }}$ ed. (1987) chap.8.

55 Much information in this section is taken from the Scottish Executive website and newsletters of the project team and programme board published May 2004 - June 2005. Available at <www.scotland.gov.uk> as at 21 July 2005. 
structure and governance of the new body. ${ }^{56}$ This consultation paper on the proposed Police Bill made it clear that the tripartite system of accountability would be reflected in the new structure. A Service Authority would provide the common police services and maintain the Scottish Drug Enforcement Agency (SDEA). This very much based on the NCS / NCIS model but with the Scottish Government proposing a greater level of democratic local input than retained in the former bodies prior to their merging. ${ }^{57}$ In England and Wales at the same time the creation of SOCA by national Government removed any residual vestige of the tripartite system being reflected in the national structure as there is no division between officers and scrutiny body, instead all members sit together as the Board of the Agency. ${ }^{58}$

Two useful different perspectives on the establishment of SOCA are by Harfield and by Bowling and Ross. ${ }^{59}$ Harfield states bluntly two of the most important issues "its creation begs a number of questions about priority setting and accountability." 60 In both of these areas the existing national control is consolidated. In a sensationalist but compelling conclusion to an overall fairly balanced article Bowling and Ross highlight:

"Never before has central government commanded such a high degree of control over police agents, who have traditionally been independent ... There will be no police authority or independent monitoring commission for this agency, nor any prospect of democratic accountability to local communities." ${ }_{61}$

This neatly summarises the trends and concerns explained by this and other authors cited previously. The way that SOCA has been established contrasts with developments in Scotland that retain more connection to the traditional tripartite structure. The control and governance of SOCA abandons the traditional British constitutional notions of separation of power and checks and balances in pursuit of shared work against crime. Rather than establish a body and scrutiny element the structure emphasises the team working together to achieve the organisation's objectives. Arguably it is legitimate for Government to assert that there are shared common goals in our society that all can agree with including the fight against serious and organised crime but

56 Scottish Executive, Edinburgh, 2005. See paras.2.11-2.29.

57 These changes were enacted by the Police, Public Order and Criminal Justice (Scotland) Act 2006. The Scottish Police Services Authority (SPSA) comes into operation on 1 April 2007, bringing together the police training, criminal records, information systems development and forensic science service mentioned. The renamed Scottish Crime and Drug Enforcement Agency (SCDEA) is responsible to the SPSA for operational matters; the new name reflects increased emphasis on tackling serious and organised crime. Some details taken from the Scottish Executive website and http://www.sdea.police.uk/aboutus.htm (06/03/06).

58 For composition of the Board of SOCA see Serious Organised Crime and Police Act 2005 Sch.1, Part 1.

59 C. Harfield "Soca: A Paradigm Shift in British Policing" 2006 (46) Br J Criminol 2006 743; "The Serious Organised Crime Agency - should we be afraid?" B. Bowling \& J. Ross [2006] Crim LR 1019.

60 Ibid. p.743.

61 Op. cit., p.1032-33. The authors appear unduly pessimistic about the ability of a SOCA Director-General to stand up to political interference by a Home Secretary, pp.1026-27. 
the lack of safeguards in this more politicised system gives cause for concern due to the reasons safeguards are introduced in the first place.

\section{Specific Issues in Creating a National Force}

Many features of the current system readily lend themselves to being incorporated as parts of a national police force system. For example the national and local policing plans. By the Police and Magistrates' Courts Act 1994 the Secretary of State may set objectives for the policing of the areas of all police authorities, (section 37) and set performance targets (section 38). Police authorities can set local policing objectives (section 7) provided they are not inconsistent with the national ones.

The Police Reform Act 2002 introduced the National Policing Plan. "The single place where the Government's priorities, performance indicators and plans for new development come together." (Cm S326, para. 7.21) The plan sets out "strategic national priorities for the police service and the indicators against which the performance of the service will be judged." ${ }^{62}$ In the third plan the liaison between the Home Office and senior police officers is explicit:

"The Home Secretary's key priorities for the police service for 2005-08 have taken account of the Association of Chief Police Officers' (ACPO) National Strategic Assessment (see 2.4 2.5). That Assessment, and this Plan, set the framework for policing in England and Wales against which forces and authorities should undertake their planning." $" 63$

The Government set out five priorities for policing at a national level. Locally there are three year strategy plans, introduced by the Police Reform Act 2002, section 92. There is no reason why these various systems could not continue substantially unchanged with a national police force. That is true with the replacement of the National Policing Plan after the Police and Justice Act 2006 (Schedule 2). This takes account of the need to recognise that policing is a partnership activity not just to be left to the police.

Instead measures are contained in the November 2006 updated National Community Safety Plan 2006-2009 published by the Home Office. The measures in the Act also allow for potentially less prescription in objective setting and the requirements for plans imposed on local police authorities by giving the Home Secretary greater discretion.

Increased managerialism and control through audit have been controversial since the 1980s, with greater significance after the introduction of Best Value by the Local Government Act 1999. ${ }^{64}$ The emphasis on targets and evaluation would make merging police forces across the whole country more straightforward as they are used to substantially the same inspection regimes.

62 Para. 1.2. The National Policing Plan 2003-2006 (Home Office November 2002).

63 National Policing Plan 2005-08. (Home Office, London, 2004), p.5.

64 This as with policy themes such as citizen as consumer and centralisation (above) have been equally evident in other areas of national policy such as education and in health, the latter charted in part by Professor Harrington "Medical Law and the Changing NHS: A Study in Rhetoric" inaugural lecture, University of Liverpool 5 March 2007. 
A similarity is that the PSNI is currently inspected by HMIC as are the English and Welsh forces. ${ }^{65}$ Her Majesty's Inspectorate of Constabulary for Scotland carry out the same wide range of work as their comparators in England and Wales. This similarity would make integration of inspection a relatively straightforward matter to still be undertaken largely at levels below the national police force level. ${ }^{66}$ Therefore there would still be local and national targets and performance indicators (considered further below).

\section{Leadership of the Police Force at National Level: Symbolism; The Intelligence Function}

Keeping the Chief Constable title for the head of the national force might not reflect the scale of the change in establishing the new body. Possibly the head of a national police force could be called a Commissioner. The Metropolitan Police in effect carry out some national functions at present and the Commissioner is in charge of by far the largest force in the country. This could distinguish the title of the national head from the local heads of police areas (it is suggested below that the latter could still be called Chief Constables). On the other hand the head of the national policing bodies already established are Director Generals. The head of the national police force might logically therefore also be called a Director General, however this may lead to real or perceived rivalry with SOCA.

The fundamental importance of intelligence led policing driving SOCA's work is highlighted by Harfield. ${ }^{67}$ Of particular importance would be the role of Special Branch in supporting SOCA and the security services at national level and the police at a lower level. The recent reorganisation of Special Branch to enable more national coordination and regional cooperation should ensure that the work and organisation of Special Branch could integrate easily into a new national structure with regional or county sub-divisions. ${ }^{6}$ Local police intelligence has been of great importance in supporting the work of the National Criminal Intelligence Service and the National Crime Squad. With a single national police force with dedicated points of contact it could be easier for local officers to pass on relevant intelligence. For example neighbourhood officers might raise suspicions about individuals and institutions that would support the criminal intelligence work of SOCA on curbing money laundering and offences related to the proceeds of crime. ${ }^{69}$ Clear systems could be put in place to enable this. There is no natural dichotomy between local and national intelligence - the two are inextricably interlinked both up and down. This point was spelt out by the

65 Sections 41 and 42 Police (NI) Act 1998 as amended by Sch.6 Police (NI) Act 2000 and s.3 Police Reform Act 2002.

66 See Her Majesty's Inspectorate of Constabulary for Scotland Corporate Plan 2003-2006 (HMIC, 2003) and Inspection Programme 2005 - 2007, both available at <http://www.scotland.gov.uk/Topics/Justice/Police/15403/2058> 23 July 2005.

67 Loc. cit. at p.746-7.

68 On changes to the organisation of Special Branch see Cm. 6167 p.26 and Reid, loc., cit. (2003) 746-747 at pp.504-07.

69 For background see R. Stokes and A. Arora "The Duty to Report Under the Money Laundering Legislation Within the United Kingdom" [2004] Journal of Business Law 332; C. Walker Blackstone's Guide to the Anti-Terrorism Legislation (OUP, 2002) 69-74. 
Merseyside Police Chief Constable, Bernard Hogan-Howe, writing about gun crime:

"There's also a vital part to play in dismantling the illegal importation and supply of weapons. We need the Serious and Organised Crime Agency to take this issue as a top priority. Currently their plan targets serious criminals who use firearms. Again in my view, any criminal who has a gun is a serious criminal. It's the minor disputes between younger, disorganised criminals that lead to many of our urban shootings." $" 70$

\section{Leadership and Management of the Police Force below National Level}

There is no reason why the local heads of police areas could not continue to be called Chief Constables in each local area. There will still be a need for senior management structures below national and indeed regional level. These could be at the level of one or more counties. Possibly the strongest benefit of a good local Chief Constable is the image and practice of local leadership, this would still be essential if police officers on the ground are not going to feel remote from their senior management. The Crown Prosecution Service operates with a Chief Crown Prosecutor at each local level, there is no reason why local police area Chief Constables could not be similar in status to local Crown Prosecutors. However the financial benefits of creating a national police service would presumably not be great unless there were far fewer than the 43 police force areas (in England and Wales) at present. This could lead to opposition from existing police chiefs as the opportunities for senior roles and the status that they carry will be more limited than at present. It can be suggested that "the fairly hostile reaction from [some] Chief Constables to the now defunct plan to amalgamate a number of smaller UK forces can be attributed in part to a perceived loss of professional autonomy." 71 A related organisational issue is that regional points of contact will still be needed with SOCA, as has been the case with NCS and its structure of regional offices. If SOCA regional offices are located co-terminus with police regions that could make liaison easier and more effective than at present.

\section{Police Training and Equipment}

It can be argued that a national police force would hinder the need for police training to take account of local diversity and conditions. However, this would be done during the in force parts of the training as at present. This could also be done to some extent at regional level, as at present. In this respect the future role of Centrex is significant in that there has been an increased emphasis by the 'national' police training body towards more local as against regional training. Centrex, the Central Police Training and

70 The Daily Telegraph, 26 February 2007. On the broader links see Transnational Organised Crime: Perspectives on Global Security, A. Edwards \& P. Gill (eds.) (2003).

71 A point more clearly articulated by the journal's anonymous referee quoted here than me. Hogan-Howe has proposed the creation of regional Commissioners. The Times 19 September 2006. 
Development Authority, announced in the Summer of 2005 that it was closing three of its nine regional training centres, in Kent, Cheshire, and Gwent. This decision was because of "the migration from the current Probationer Training Programme (PTP) which was delivered regionally, to the new Initial Police Learning \& Development Programme (IPLDP), designed for local delivery of probationer training in force." 72 It was said that in line with Home Office policy the principle of the IPLDP is "that the main responsibility for the training of new officers should rest with forces. Officers will be trained more closely within the communities they will ultimately serve, with less emphasis on long periods of residential training." $" 73$ In Scotland decentralisation of other parts of training from the Scottish Police College to forces has been considered and "[t]here are no current plans to change the overall balance of police training between the College and individual forces." 74

In a recent development the National Policing Improvement Agency (NPIA) is created by the Police and Justice Act 2006. Coming into operation on 1 April 2007 the NPIA will replace and take on much of the work of Centrex and PITO. In an alarming development and emulating what was done with SOCA the Chair of the new Agency was appointed before the Agency had been approved by Parliament. This appears to show a shocking contempt for Parliamentary democracy. ${ }^{75}$ The NPIA can be seen as a further development in enhancing the professionalism of the police and encouraging high professional standards, following measures like introducing the Code of Professional Standards for police officers. ${ }^{76}$ To some extent the shift towards emphasis on quality management of officers by police leaders has also helped increase professionalism. ${ }^{77}$

It can be argued that it would be easier to address issues of discrimination in use of police powers, both in training and in management if there was a national structure rather than 43 different police forces. The well documented wide disparity of use of stop and search powers is a particular cause for concern. ${ }^{78}$ Greater national influence in some areas of policy and training may help avoid infringement of rights by the officers of a national force. (On complaints investigation see below). Multiculturalism and integration of minority ethnic groups are key areas of political debate with all main parties

72 Centrex News Release "Ashford, Bruche \& Cwmbran Police Training Centres to close in May 2006" 21 July 2005.

73 ibid. By contrast Morris and Hawkins in the USA advocated adopting the British regional training approach in 1970. Loc. cit. at pp.96-98.

74 Review of Common Police Services website as above, Frequently Asked Questions, Question 13, dated 7 March 2005.

75 Peter Holland (a Board member of Centrex) was appointed as the first chair (designate) of the NPIA in September 2006. Press release 7 September 2006. <http://www.centrex.police.uk/>. See also <http://www.npia.police.uk/>.

76 Home Office consultation, 27 February 2006.

77 Centrex Chief Executive Norman Bettison for example was recognised by the Chartered Management Institute. Centrex press release 29 July 2005.

78 L. Lustgarten "The future of stop and search" [2002] Crim LR 603. P. Waddington, K. Stenson \& D. Don "Race, and Police Stop and Search" (2004) 44 Brit J Criminol 889. 
supporting both. A national police force may make it easier to spread best practice on how the police can help rather than hinder these processes. ${ }^{79}$

Police tactics and equipment change to meet the threats they may have to face. Changes in equipment and tactics might also change the situations in which the police may come into contact with members of the public. Training is extremely important in ensuring that new equipment is used in a way which reflects officers' right to use reasonable force in carrying out their duties. Police equipment has changed greatly in the past decade which raises old legal issues in innovative situations. While firearms are not routinely deployed (confounding past pessimists), defensive body armour is now commonplace. There has been an increase in equipment that can be both offensive and defensive. New side handled batons introduced in 1995, or an alternative metal telescopic extendible truncheon replaced the traditional truncheon. The deployment of CS spray after trials in 1996; pepper spray has been trialled (for example by Sussex Police in 2001); plastic baton rounds deployed to all forces (apparently without any local consultation or democratic debate) in 2001 and electric stun gun 'tasers' deployed as well after trials in 2003 - 2004, these latter in an attempt to minimise use of lethal force when police officers would previously have had no alternative. Amnesty International is opposed to any relaxation in the rules regarding use of tasers because of research from the United States. ${ }^{80}$ Given the deployment of controversial equipment such as plastic baton rounds being sanctioned by the Home Secretary it can be argued that a paramilitary police force would be more likely if decisions on all equipment are made centrally rather than there being local choice about such issues (as with deployment of cs spray and types of batons and tasers). ${ }^{81}$ There appears no problem at present with different forces trialling equipment and best practice being spread from the results of those trials. Ormerod and Roberts, citing Lord Fowler, point out that excessive central direction could "inhibit individual forces from developing pioneering approaches". ${ }^{82}$ On the other hand reduced cost of equipment being purchased centrally and dissemination of best practice in training, as well as reducing cost of training, could be arguments in favour of a national force. ${ }^{83}$

Call handling is a particular burden for the police - essential to do the job but leading to dissatisfaction and sometimes complaint if the large volumes of

79 See D. McGoldrick "Multiculturalism and its Discontents" (2005) 5 HRLRev 27; Improving Opportunity, Strengthening Society: The Government's strategy to increase race equality and community cohesion (Home Office, London, 2005); HOPR "Tackling Extremism Together: Working groups report back to Home Secretary" 22 September 2005.

80 Press Release 30/11/04; United States of America - Excessive and lethal force? Amnesty International's concerns about deaths and ill-treatment involving police use of tasers. The IPCC welcomed tasers but supported Amnesty's concerns $c f$ press releases 30/11/2004 and 15/09/2004

81 For example in Wales three forces have deployed tasers at different times and one not introduced them yet. "Wales-wide backing for Taser guns" BBC News Online <http://news.bbc.co.uk>22/08/2005.

82 Loc. cit. p. 145.

83 For background Safer Restraint (Police Complaints Authority, London, 2002); B. Rappert "Constructions of Legitimate Force: The Case of CS Sprays" (2000) 42 Brit. J. Criminol. 689; Bailey et. al. pp.400-410 (also $4^{\text {th }}$ ed., 1995, 169-77). 
telephone calls from the public to the police do not result in the desired response. ${ }^{84}$ With a huge increase in volume of calls public dissatisfaction with call handling (and subsequent response) are an area where the usually popular British police are criticised. The Government are considering introducing a national non-emergency number (to be telephone number 101, piloted in several local authorities from Summer 2006). ${ }^{85}$ This should divert some of the many calls not about urgent matters (or police matters at all) from police switchboards allowing police operators and officers to concentrate on more serious reports. If such a number were introduced the public would see no change in this area if a national force were then created.

\section{Local Accountability: Scrutiny v Accountability}

Arguments about accountability and governance reoccur over time. Definitions of terms may overlap. Lustgarten points out that "there is no necessary connection between democracy and any particular mode of organisation and control of the police." He asserts "what is really at issue is the degree of control various political institutions are to have over the police." ${ }^{86}$ Marshall and Loveday believe that there are three forms of control: "administrative, judicial, and political". They argued that

"more effective accountability of the police may most appropriately be found not in extension of political control but in more effective complaints and consultation machinery and in the acknowledgement of a wider scope for questioning and debating the exercise of police powers". ${ }^{87}$

There have been great developments on the first two but it appears very little scrutiny by the majority in Parliament or media of the last.

Regardless of local or national accountability methods local scrutiny will be required to ensure that the police is operating efficiently and effectively at a local level. Without this the force could not meet the national policing objectives and it has been suggested above that local objectives would still be needed. Inspection of the police locally would continue as above with inspection more easily possible at regional as well as national level without having to pick individual forces as building blocks to use as the subject for any inspection above county force level as at present. This however is about scrutiny rather than accountability and may not satisfy those concerned with policy and political priorities for the police. ${ }^{88}$

${ }^{84}$ See First Contact - A Thematic Inspection of Police Contact Management (HMIC, 2005).

85 See David Blunkett's speech to Superintendents' Association Annual Conference HOPR "Turning The Police Service Into A Public Service" 14 September 2004.; Building Communities, Beating Crime: A Better Police Service for the $21^{\text {st }}$ Century (Home Office, London, 2004); Local Government Association report to Safer Communities Board, item 2 Appendix A, 17 July 2006.

86 L. Lustgarten, The Governance of the Police, (1986) p.1. For illuminating discussion of accountability and governance see chap. 10 .

87 Loc. cit. p.304 and p.296 respectively. $C f$ discussion at $4^{\text {th }}$ ed., 2000 p.ix.

88 For a critique of police authorities from a police chief and debate on force structures see I. Oliver, Police, Government and Accountability (1987) Part V. 
The 2004 White Paper gave an indication here as to how police could be held to account at local level - even under a national structure - more than happens universally at present. Some forces have pioneered local problem solving groups at neighbourhood or local authority ward level, some in the form of tasking groups across a collection of wards which make up a police neighbourhood. These will usually involve community groups, housing associations, possibly business, and local district councillor representatives meeting with the responsible police neighbourhood or community Inspector or a sergeant and constable on their team. ${ }^{89}$ An example from one city is the 'Anfield, Everton \& County Policing Initiative Steering Group Meeting'. This monthly steering group meeting covers three Council wards in north Liverpool. The format of meetings includes matters arising, a police report reviewing work since the last meeting, and issues to be addressed in the next period raised for each ward by those attending. ${ }^{90}$ Similar teams are being established on Council ward basis in the London Borough of Camdem. Eight out of eighteen wards have teams. ${ }^{91}$ Forces also have inter-agency groups at basic command unit (BCU) level, and district council level, usually under Crime and Disorder Act structures. These structures in place in some forces, that the Government is encouraging, could be the building blocks of scrutiny and cooperation with the police, albeit not direct political accountability, under a new national structure. The Home Secretary, Charles Clarke, gave a speech to the Police Federation Annual Conference in June 2005 stressing themes such as these. ${ }^{92}$ This was repeated in his response to the HMIC report in September 2005. Charles Clarke said:

"These local teams will form part of a basic command unit, where a senior officer will be able to set unique priorities for their patch to address problems in that area." He continued "with local accountability for tackling crime delivered by neighbourhood policing, bigger, more strategic constabularies will mean we have forces ready and equipped for policing in the $21^{\text {st }}$ century."

Edwards argues there is a potential flaw in this approach:

"Unless genuine decision-making powers is devolved, the devolution of authority to middle management does no more than create potential scapegoats within the intermediate ranks." ${ }^{93}$

89 Refer to: Confident Communities in a Secure Britain: The Home Office Strategic Plan 2004-08 Summary (Home Office, London, 2004), pp.10-12. The November 2003 Consultation Paper Policing: Building Safer Communities Together contained discussion on many of these issues (Home Office, London, 2003).

90 Referred to in Liverpool City Council report: "North Liverpool Neighbourhood Manager report to the Anfield, Tuebrook \& Stoneycroft and Old Swan Neighbourhood Committee", 30 June 2005, agenda p.21.

91 See M. Eley "Policework returning to normal after bombs" Hampstead \& Highgate Express 26 August 2005, p.25.

92 HOPR Reference: Police Fed, 3 June 2005.

93 Op. cit., p.319. 
The direct involvement of Government in tackling street crime in the worst areas does appear to have been a success in 2002-2003. ${ }^{94}$ However Merseyside Police have reportedly stated that a rise in robberies in 2005 followed a Home Office decision to switch attention from street crime to tackling anti-social behaviour. ${ }^{95}$

A further element of elected involvement and integration for the present system would be achieved by the addition of the local authority executive member for community safety as an ex officio member of the police authority. Would there still be any need or role for a local police authority with a single force? There could still be political involvement on this level in addition to those outlined above except that the role of any such area body could be either purely advisory, subject to the ideas below, or have statutory remit to take certain decisions as co-decisions. For example the equivalent police area authority could be consulted on the local plans and targets or it could have a legal role whereby the area authority and the police chief at that level had to both agree the local plans and targets. ${ }^{96}$

\section{Complaints Investigations}

Establishing a national police force would appear to strengthen arguments in favour of a single independent national body to investigate police complaints. At present there are different systems in England and Wales, Northern Ireland and Scotland. In England and Wales the Independent Police Complaints Commission; in Northern Ireland the Police Ombudsman and in Scotland investigation by the police themselves or by the Area (formerly Regional) Procurator Fiscal independent of the police if an allegation that an officer on duty has committed a crime. ${ }^{97}$ While the systems appear very different they are all similar in that it is only the most serious complaints that are investigated independently of the police. ${ }^{98} \mathrm{In}$ Scotland the Procurator Fiscal service is in charge of prosecutions, that may give the impression that they work too closely with the police to be independent. The Supporting Police, Protecting Communities paper includes proposals for an independent police complaints body in Scotland while retaining the role of the Procurator Fiscal service after strong support in the

94 See Reid (2003) p.506-507.

95 See "Robberies on the rise" South Liverpool Merseymart, 8 September 2005, p.2.

96 By contrast the opposition Conservative Party argued for a completely different policy in their manifesto for the 2005 General Election. "To give local people a real say, we will replace appointed Police Authorities with directly-elected Police Commissioners - directly accountable to their local communities." Like the Government they supported more neighbourhood policing. Action on Crime: Conservative Manifesto 2005 chap.2, p.5. Available at <http://www.conservatives .com> as at 6 July 2005.

97 For information on the IPCC see Reid (2005) loc. cit., at 233-235. On Northern Ireland refer to: < http://www.policeombudsman.org/> viewed at 30 July 2005. On the Scottish system see "Complaints Against the Police" leaflet, Scottish Executive, Edinburgh 2003 (available at <http://www.scotland.gov.uk/Topics/ Justice/Police> viewed at 8 March 2007).

98 For other jurisdictions and comparative analysis see A. Goldsmith and C. Lewis (eds.) Civilian Oversight of Policing (2000). 
consultation. ${ }^{99}$ Arguably this would not be sufficiently independent. The fact that different systems exist in the three jurisdictions would not prevent the three police forces becoming part of a single force. The IPCC has no jurisdiction in Scotland at present, including over English and Welsh officers deployed there for mutual aid, an issue that arose in relation to complaints about the G8 Summit in July 2005. This necessitated the IPCC publishing a statement on its website to this effect on 7 July 2005. Similarly and confusingly it cannot investigate complaints against SOCA relating to Scotland which must appear inconsistent. While different systems could remain if there was a single force the complaints system could logically be modernised and brought under a single heading (certainly for Great Britain) at the same time.

In some cases where the police investigate themselves it is not appropriate for the same police force to carry out that investigation. Therefore the complaint is investigated by officers from a different force. In these cases there need be no change to the present system except instead of an officer from an outside force involved in the investigation it would be officers from a different geographical area of the police that would be appropriate to carry out any investigation of a complaint.

\section{Interaction with National and International Bodies}

It can be argued that cooperation with international bodies should still be through the national body responsible if that is the current situation. For example that was NCIS on liaison with Europol and is now SOCA. SOCA is the liaison with several other international bodies as well including the International Criminal Police Organisation (better known as Interpol). The UK National Central Bureau of Interpol was part of NCIS. There may also be direct operational contact between British and other European police forces at present. This work could be more effectively carried out and supervised by a national police force and be more transparent and accountable.

Bowling and Ross mention "It is implicit in the government's current programme of reform that SOCA represents an opportunity to raise UK transnational policing to a new level of efficacy."100 This they point out must be judged by success in dealing with harm caused locally. With intelligence work integrated in a national police service as discussed above this efficacy could be increased further.

\section{The European Dimension}

European Union co-operation in the area of Home Affairs has been most high profile concerning measures against terrorism introduced since 2001 2002 but this has been based on wider criminal law co-operation. Furthermore many of the most high profile signs of increased EU cooperation against terrorism pre-date September 11. For example Eurojust had been proposed by the European Council at Tampere. The Commission issued a report supporting such a body in November 2000 to:

99 Loc. cit., part 9. The Police, Public Order and Criminal Justice (Scotland) Act 2006 establishes a Police Complaints Commissioner for Scotland.

100 Loc. cit., p.1032. 
"reinforce the fight against serious organised crime, this unit shall have the task of facilitating the proper co-ordination of national prosecuting authorities and of supporting criminal investigations in organised crime cases in particular on the basis of analyses conducted by Europol". ${ }^{101}$

However this was when established specifically to be wider than just serious organised crime or terrorism. The Council decision came into force on 6 March 2002, at this point Eurojust had been operating provisionally since March 2001 on cases of terrorism, money laundering, trafficking in human beings, trafficking in stolen vehicles, serious fraud (including tax fraud), internet fraud; and forgery of documents. ${ }^{102}$

"Each of the 15 member states has contributed either a senior prosecutor, judge or police officer to Eurojust to improve the co-ordination of investigations, prosecutions and judicial cooperation on EU cross-border serious crime."103

Specifically in relation to terrorism the Committee on Citizens' Freedoms and Rights, Justice and Home Affairs published its Report on the role of the European Union in combating terrorism on 12 July 2001. ${ }^{104}$ This built on the constitutional provision for Member States to cooperate against terrorism at European level contained in Article 29 of the Treaty on European Union and the equivalent provision relating to a minimum harmonisation of constituent elements of criminal acts contained in Article 31(e). The report begins by listing four pages of provisions or resolutions relevant to cooperation on crime and terrorism over more than 40 years. These include the Europol convention establishing the European Police Office. ${ }^{105}$ The report highlights a number of factors that show the necessity for international cooperation. These include identification of a "new form of terrorism" that

"stems from the activities of networks operating at international level, which are based in several countries and exploit legal loopholes arising from the geographical limits of investigations" (page 9 paragraph G).

This is a very accurate description of Al Qaeda.

'Computer terrorism', 'environmental terrorism' and the risk of terrorism using chemical, biological and toxic substances are specifically identified (page 11 paragraphs $\mathrm{W}$ and $\mathrm{Y}$ ).

International cooperation is clearly needed to deal with these threats but there appears to be very limited accountability of such work. Article 34 of the Treaty on European Union specifically provided for cooperation between Governments.

101 European Union On the Establishment of Eurojust 22 November 2000 $\operatorname{COM}(2000) 746$ final, p.2.

102 2002/187/JHA (Official Journal L 63).

103 HOPR 181/2002, 28 June 2002.

104 European Union, 2001.

105 OJ C 316, 27 November 1995, p.1. For other sources see Council of Europe The Fight Against Terrorism: Council of Europe Standards (Council of Europe Publishing, Strasbourg, 2003). 
Given that co-operation is through the Council accountability in relation to any relevant decisions and structures established can only be at the national political level with no direct accountability to democratic institutions. Concern can be raised about the accountability both of Europol and generally of policing and police cooperation at European level. Cooperation in police operations across Europe was increasingly important in the second half of the 1990s and has been given increased impetus following the events of 11 September 2001. British involvement in cooperation at European level is entirely outside of the traditional framework of accountability of the police in the UK. As cooperation increases it is therefore appropriate to consider who does scrutinise and control European cooperation. The Home Secretary plays a direct role in meetings of the Council of Ministers and is accountable to Parliament for that. The Council appoints the Director and the Deputy Directors of Europol and adopts the budget. However arguably most important in the political structure for the scrutiny of the EU's Executive (and of EU wide bodies) are the Committees of the European Parliament. The EU Committee on Citizens' Freedoms and Rights, Justice and Home Affairs has responsibility for
"closer cooperation among police forces, customs authorities and other competent authorities in the Member States, both directly and through the European Police Office (Europol), in accordance with Articles 30 and 32 of the EU Treaty". ${ }^{106}$

That scrutiny is necessarily going to be limited. Europol does submit an annual report to the European Parliament. It also has its own Management Board composed of one representative of each Member State. This though is about running of the organisation not necessarily accountability. On the other hand there is a Joint Supervisory Body with the task "to review the activities of Europol in order to ensure that the rights of the individual are not violated by the storage, processing and utilization of the data held". ${ }^{107}$ The creation of a national police force with a clear system of accountability could at least make more transparent the British role in European police cooperation both on information and operationally.

Anderson and Den Boer made the point in 1994 as to how European police cooperation could impact on citizens: it is about many things "civil liberties, data protection, criminal law procedures, accountability and the raw struggle for power, influence and resources". 108 This was before the concrete structures that exist today had been put in place. Den Boer predicted the expansion of Europol to an operational role in 1994. ${ }^{109}$ That appears increasingly likely today in terms of Europol becoming directly involved in coordinating police operations against international crime rather than just transferring and analysing information. Accountability does not appear to

106 Rules of Procedure of the European Parliament 15th ed. - February 2003 Renamed Committee on Civil Liberties, Justice and Home Affairs, July 2004 with similar remit.

107 Europol website <http://www.europol.eu.int/index.asp?page=home\&language=> viewed at 17 September 2003).

108 M. Anderson and M. den Boer (eds.) Policing Across National Boundaries (1994), Preface, $p . x$.

109 Supra, p.175. 
have matched the growth of structures. The draft EU Constitution did not give Europol any wider role but development could continue organically as now. In relation to the proposed EU Constitution Professor Monar argued that police cooperation is "One of the few areas where the Convention managed to simplify the treaties". Monar made the point that if Europol had been given an operational role then the accountability structures at EU level would have to have been increased. ${ }^{110}$ At present there are only the national structures regarding any cooperation of police forces on operational matters. There should be more emphasis on accountability at both Member State and European level. In the UK how does one know what international police operations have taken place? One cannot scrutinise without knowing what work has been done. There appears to be no method or requirement for publicly reporting on this at any level of the political structure in Britain. ${ }^{111}$ This could be incorporated if a national police force is established.

\section{The Obstacles to a National Police Force}

It has already been noted that there is nothing in international principles or jurisprudence that requires local police forces and local accountability. Problems with local accountability in this context have also been highlighted above. There are theoretical or metaphysical concerns that mitigate against a national police force. The fear of dictatorship is perhaps the most powerful. It can be argued that this is about police powers rather than control. The police have been given sweeping powers in recent years that could be readily abused if not used strictly in accordance with the legal limitations on them. ${ }^{112}$ Notable are dispersal orders and anti-social behaviour powers; extended detention without charge; Terrorism Act stop and search powers; and restrictions on public assembly. The extensive use of Terrorism Act stop and search powers against peaceful protesters is particularly worrying. There is no evidence that abuse is widespread or happening systematically, although the police appear to be systematically using anti-terrorist powers when it is questionable whether there is any specific terrorist threat with little protection provided by the courts. ${ }^{13}$ However the extension of power of arrest potentially for all offences gives police officers much greater scope to interfere with individuals than before. Under a more authoritarian Home Secretary and less tolerant and professional police force the collective abuse of such powers - even to the extent of a slight change in emphasis - could be used to further an autocratic Government nationally or in the regions.

The history, tradition and diversity of areas today could lead to emotional resistance to a national force. However apart from former officers it is

110 Europe in the World Centre seminar, University of Liverpool, 16 December 2004.

111 Considered further in Reid (2005) at $253-254$.

112 Similar developments can be charted in Ireland. E. Campbell "Organised Crime and the Culture of Control in Ireland" conference paper, SLSA Liverpool, March 2005.

113 See Liberty briefing "The Right to Protest" as at 31 August 2005. Casualty of War: 8 Weeks of counter terrorism in rural England (2003). <http://www.libertyhuman-rights.org.uk/> $R$. (on the application of Gillan \& Quinton) $v$ Commissioner of Police of the Metropolis [2006] UKHL 12, HL 8 March 2006 (the Law Lords taking a notably more liberal stance however than the Court of Appeal). 
inconceivable that there would be much call today for reinstatement of old forces such as the City of Liverpool Police, although older residents might like to see again operational police stations in the heart of each community as existed in the city under that force. ${ }^{114}$ Less abstract Chief Constables and other senior officers are not going to want to give up their status and operational independence. There is a more significant argument that the existence of independent county based police forces at the moment protects police recognition of, understanding of and suitable approaches to policing the diversity of different parts of the country. It can seriously be argued that insufficient attention would be given to some areas and parts of the country under a national police force concerned with population and cost driven statistics. This concern may be particularly prevalent in rural areas. There could be a natural tendency to concentrate on the large urban centres of population.

"The Metropolitan Police Service is the largest force, accounting for 21 per cent of all officers on 31 March 2004. The eight Metropolitan forces (Greater Manchester, City of London, Merseyside, Metropolitan Police, Northumbria, South Yorkshire, West Midlands and West Yorkshire) accounted for 45 per cent of all officers." 115

However it should be borne in mind that even 'urban' forces such as Merseyside and West Yorkshire are not homogenous but include extensive areas of suburban, small town and countryside or rural areas and that these forces do have experience of policing widely different types of area.

There may be further concern that a national police force could be London centric given as noted above that "[t]he Metropolitan Police Service is the largest force, accounting for 21 per cent of all officers on 31 March 2004". However nearly $80 \%$ of officers would not be London officers, giving other centres of gravity in any internal force lobbying for resources or influence.

If Home Office forces are to be merged this would also be a logical time to abolish most of the non Home Office forces and to integrate them into the national force. This could apply for example to the British Transport Police (which operate throughout Great Britain already), Port of Dover Police and Mersey Tunnels Police. This would follow the start made in London by the Government in 2005. The Royal Parks Constabulary was abolished by section 161 of the Serious Organised Crime and Police Act. There was no explanation as to why this was connected to serious and organised crime. Members of the public presumably wanted parks police to deal with less serious and more disorganised crime.

114 See W. Cockcroft From Cutlasses to Computers: The Police Force in Liverpool 1836-1989 (S.B. publications, Market Drayton, Shropshire, 1991), particularly pp.78- 81 .

115 Home Office Statistical Bulletin 13/04 29 September 2004 - Police Service Strength England and Wales, 31 March 2004 O. Christophersen \& J. Cotton (Home Office, London) para.(f), p.5. 


\section{The Cost of Establishing a National Force}

There may be very large initial start up costs, more if it was not just for England and Wales. These could inhibit any Government establishing a national force. However this paper assumes that there will also be significant savings - in procurement of equipment and technology, vehicles and uniforms for example and in reduced administration costs by the standardisation of procedures across forces. A national force could benefit from significant economies of scale. Reduction from 43 to just 1 if only England and Wales is covered should lead to significant administrative savings by the standardisation and simplification and reduction of administrative procedures at local, regional and national levels. Management and administrative jobs could be cut. These savings would reduce start up costs. Further, there is a great deal of standardisation at present, limiting increased costs of having to change systems, equipment and other supplies.

The vast majority of police funds comes from central Government directly or indirectly but a significant if small percentage is raised by local taxation. Central Government may be unwilling to provide the extra amount to pay for a national force from taxation revenue (putting up direct taxes is not a policy of the British Labour Government or Conservative Opposition). Local authorities may be unwilling to continue to pay a levy from local taxation (Council tax in England and Wales) to the cost of a police force over which they retain no authority. The levy could be paid for by 'top slicing' local authority grants, as was previously done with the police grant to pay for NCS and NCIS, however the amount taken from each authority may bear no relation to the local policing services provided by the national force. A form of minimum guarantee of services could be one measure adopted to placate local authority opposition.

\section{The Pensions Issue}

One of the biggest practical problems for establishing a national police force is the cost to current police authorities of pension payments for retired officers. There is no invested pension fund for police officers and therefore the payment of pensions is a very significant proportion of police authority expenditure. For example for Merseyside payment of pensions amounts to $17 \%$ of the police authority expenditure. ${ }^{116}$ For England and Wales in $2003 / 04$ nearly $1 / 3$ of the amount spent on police pay was spent on pensions for retired officers. ${ }^{117}$ Creation of a pension fund for the national force would require a large amount of money to be put aside for current payments or invested by the Treasury for future payments or both. Government would then need to bear costs to make this politically acceptable.

This issue was reviewed at national level with a police pension consultation in 2003-2004.118 The review covered both the creation of a new pension scheme and the financing of pension expenditure. A new scheme was put

\footnotetext{
116 Merseyside Police Authority Press Release on Budget, 17 February 2005.

117 Government proposals for a New Police Pension Scheme for Future Entrants. A consultation document issued by the Home Office, the Scottish Executive and the Northern Ireland Office. December 2003. p.85.

118 ibid. See also Summary of responses August 2004.
} 
into place with effect from April 2006. ${ }^{119}$ It was intended that the new pension scheme would include all the UK (and it does take account of transfers between UK jurisdictions) and therefore this would facilitate a national force by removing one of the biggest current practical obstacles.

Personnel issues are often contentious due to the personal implications for staff involved. There is much recent experience in dealing with the personnel issues that would arise in amalgamating forces because of the formation of SOCA and the Scottish review of common police services. ${ }^{120}$ The trend of increasing the Home Secretary's powers to standardise regulations for all forces will have limited the amount of changes that would have to be made to terms and conditions for officers and civilian staff in different forces and it is suggested greatly reduced any employment law issues that could have been significant legal obstacles to amalgamation. Further standardisation of personnel procedures should also reduce costs. Recruitment of officers has been standardised by a national application form for recruiting introduced in forces in England and Wales (National Policing Plan Annex A).

Management strategies across forces and objectives for and appraisal of individual staff must be consistent with national guidance from the Home Office Police Standards Unit, drawn up with the umbrella bodies of the tripartite partners ACPO and the APA. ${ }^{121}$ The National Policing Plan makes clear that performance related pay for police chiefs, and appointment of police chiefs, will depend on their staff performance at local level meeting the national objectives and force targets. (Paragraph 4.9). Therefore little change would be needed for managing staff performance under a national force.

\section{What Would a Bill Look Like?}

A 'National Police Force' Bill could be very simple indeed. As with much recent criminal justice legislation the detail could be left to regulations to be decided upon later by the Minister. The Bill would simply abolish the local police forces and create a new Police Service. This would follow the pattern in Northern Ireland where the Police Service of Northern Ireland was created and the title of service rather than force would reflect New Labour emphasis on citizens and consumers.

It could be titled 'A Bill to abolish existing police forces in England and Wales and create a new Police Service for England and Wales.'

At present officers and civilian staff are employed by the Police Authority. They could all be transferred instead to the employment of the body the Police Service for England and Wales. Regarding legal liability in civil cases the Chief Constable currently has vicarious liability for the torts and other unlawful conduct of his or her employees. This could simply be

119 See the Police Pensions Regulations 2006 SI 3415, and Explanatory Memorandum.

120 See Review of Common Police Services Newsletter June 2005 p.4-5. <http://www.scotland.gov.uk/Resource/Doc/1101/0015389.pdf> viewed at 21 July 2005.

121 Managing Police Performance: A Practical Guide to Performance Management, September 2004. 
transferred to the Director General or such head of the Police Service for England and Wales. There is no need to change but this would be a logical time to end this anomaly whereby the police Chief is technically liable, though the Police Authority pays any damages. ${ }^{122}$ Liability could be transferred to the national police force as a body rather than onto the head personally. Legal responsibility for health and Safety issues would be transferred from the local Police Authorities to the Police Service for England and Wales (see current legislation as amended by s. 95 Police Reform Act 2002). All assets and property of the individual forces would be transferred to the new Police Service. Existing Chief Constables could simply be made Chief Constables for areas under the new force, although this article has suggested the number of sub-national force areas would need to be reduced. Their current reporting obligations to the Home Secretary and local Police Authority could be replaced by reporting obligations to the Director General. However it would be cumbersome to keep the entire framework of the Police Act 1996, as it is still clearly modelled on the tripartite structure in the Police Act 1964. The Police Act 1996 is arguably due for consolidation due to the number of changes since then. The new Bill could repeal it in its entirety, giving the civil servants a chance to draft a new piece of governance legislation applicable for a new national force in the $21^{\text {st }}$ Century.

\section{Conclusion}

This article has sought to identify, consider and analyse the legal issues that would arise if Government planned to introduce a national police force. It appears to be the case that this could be done with minimal legal difficulty and with much continuity. Members of the public would arguably see and experience little change. There are philosophical and political arguments the latter national, local and anti-authoritarian - against such a development. It would also go against nearly two centuries of tradition of British policing which has always been about policing as a local function but it would consolidate the trend of recent decades. Given the great influence now over policing by the Government - over appointments and removal of senior officers, regulations and training, targets and performance indicators and finance - the creation of a national force could simply formalise what is to a significant extent the de facto position in Britain today. It would certainly be a more honest policy for the Government to take significant responsibility as well as significant control rather than keeping an illusion of local police and local accountability which is more and more removed from the actual situation with police governance.

122 S.88(1) Police Act 1996 as amended by s.102 Police Reform Act 2002. 